\title{
Jana Pieriegud
}

Institute of Infrastructure, Transport and Mobility, SGH Warsaw School of Economics, Poland

\section{E-MOBILITY ON-DEMAND IN THE CENTRAL AND EASTERN EUROPEAN COUNTRIES: CURRENT TRENDS, BARRIERS AND OPPORTUNITIES}

\begin{abstract}
Electromobility (e-mobility) and shared mobility on-demand are relatively new research areas. Different progress has been made in different countries in these fields. The paper analyzes current trends of the development of e-mobility on-demand services (car-sharing, bike-sharing, scooter-sharing, and kick scooter-sharing) in six selected CEE countries (Poland, the Czech Republic, Slovakia, Lithuania, Ukraine, and Belarus). Identification of the main barriers and opportunities for further growth required a review the key components of national e-mobility systems, such as: demand and supply on the electric car market, charging infrastructure development, as well as available instruments supporting e-mobility. A number of absolute and relative indicators were used. The analysis confirmed that Poland and other CEE countries are still at the beginning phase of the e-mobility development. Although Poland is the leader in the CEE region in terms of the development of e-mobility on-demand services, a low charging infrastructure availability is one of the barriers of car-sharing development. Economic effectiveness of the providers' activities will be the main challenge in the coming years.
\end{abstract}

Keywords: electromobility, shared mobility on-demand, BEV, CEE, Poland

JEL: L92, L94, O18, R40, R48

\section{Introduction}

In the last few years, governments of various countries, car manufacturers, companies in the power sector and many other entities have been undertaking activities aimed at the development of the concept of electromobility (e-mobility). 
The implementation of new business models in urban mobility management is one of the factors which support this process (Figure 1).

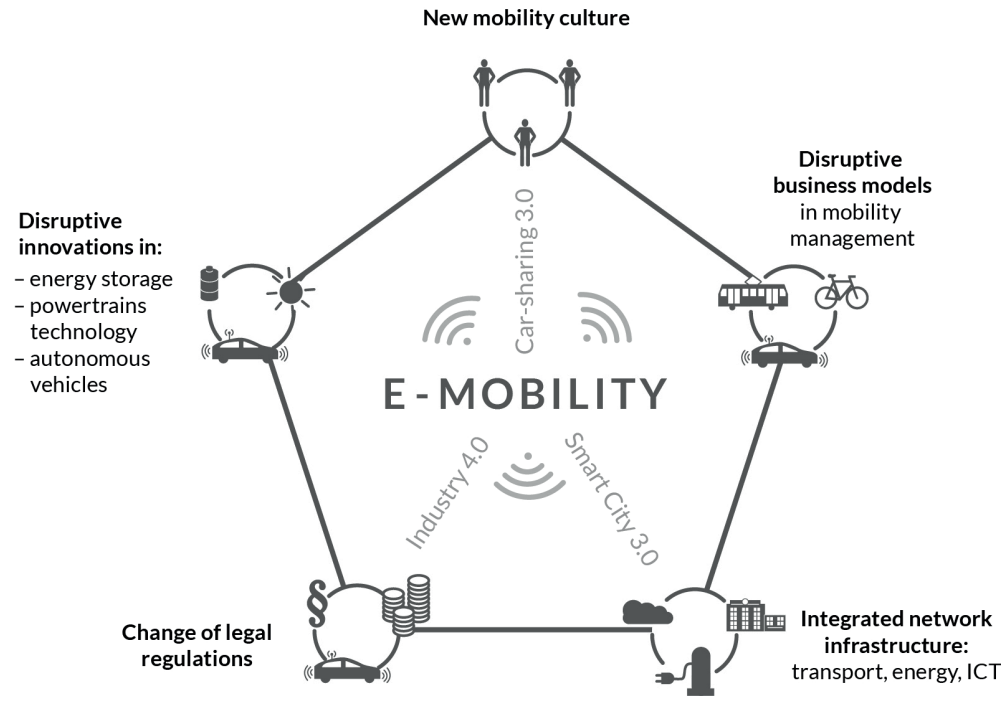

Figure 1. The Golden Pentagon of popularizing the concept of e-mobility Source: (Pieriegud 2017, p. 17)

The purpose of the article is to analyze the level of development of the shared e-mobility services as a component of the e-mobility systems in six selected countries from Central and Eastern Europe (CEE): in Poland, the Czech Republic, Slovakia, Lithuania, and in Belarus, and Ukraine. The following research hypotheses were verified:

- the availability of shared e-mobility services varies significantly across CEE countries;

- one of the factors hampering the development of electric car-sharing services is the insufficient development of charging infrastructure.

\section{Methodology and literature review}

Knowledge about the studied issue is still limited. It combines two elements: e-mobility and shared mobility on-demand. New mobility concepts (such as smart mobility, shared mobility, mobility-as-a-service) have been a subject of numerous studies (OECD/ITF, 2016; Matyas, Kamargianni, 2017; Flügge 2017). The published scientific articles and reports related to the development of e-mobility usually analyze countries belonging to the same integration groups (e.g. EU), and the basic indicators in the analyses are the number of electric cars and their share in the total number of the registered passenger cars in a given country. Researchers also compare e-mobility support instruments (Cansino, Sánchez-Braza, Sanz-Díaz, 2018; Spöttle et al., 2018). However, it is difficult to find studies in which 
the segments of electric car-sharing and micro-sharing (1- and 2-seater cars, bikes, scooters, and kick scooters) would also be analyzed in the CEE countries, including the Visegrad countries, The Baltic states, and the former USSR.

In this article, the market of each of the countries selected for analysis was first analyzed in terms of the key components of the e-mobility system: demand for electric vehicles, charging station network, available instruments for supporting e-mobility development and shared services available upon the users' demand. A comparative statement was then prepared, which also includes indicators illustrating the size of the markets under analysis and the purchasing power of the residents.

For the purpose of the analysis, data from the databases of statistical offices of the analyzed countries, European Alternative Fuel Observatory (EAFO), contained in reports and articles published by industry websites, as well as data provided by vehicle manufacturers, charging station operators, and entities providing shared mobility services were used. The analysis was based on data at the end of 2018, and in some cases the data available at the end of April 2019 were taken into account.

\section{Comparative analysis}

\subsection{Poland}

The electric car market in Poland still accounts for a very small percentage of the privately-owned personal cars. According to Samar's data, 620 electric cars of the BEV category (battery electric vehicle) and 704 PHEVs (plug-in hybrid electric vehicle) were sold in 2018. At the same time, especially in the case of fully electric cars, a very dynamic, two-digit sales growth was observed, which amounted to $45 \%$ compared to 2017 (Figure 2). The number of BEV and PHEV models available on the market is also growing. A total of 48 models covered most of passenger car segments, while the most popular BEV models were: Nissan Leaf and BMW i3, as well as Renault Zoe, VW e-Golf, Tesla Model X (Zawieska, 2019, pp. 14-15). Despite the Electromobility Development Plan adopted in 2017 and the Act of 11 January 2018 on Electromobility and Alternative Fuels, as of April 2018, no incentive system for the development of e-mobility was had been introduced in Poland. According to EAFO's data, between 2014 and 2018 the number of publicly available electric vehicle charging points increased from 119 to 836 (Figure 3). The operator of the largest electric car charging network is GreenWay Polska. In 2018, its network expanded by 83 new locations (including 68 own and 15 partner locations) to a total of 115. In autumn 2018, this operator began testing the first 12 charging stations for electric vehicles between Warsaw ( 2 stations) and the Tri-City ( 4 stations) on the A1 and $\mathrm{A} 2$ routes (6 stations). The stations were created as part of the Lotos Electro Mobility project co-financed from the Connecting Europe Facility (CEF) fund. 


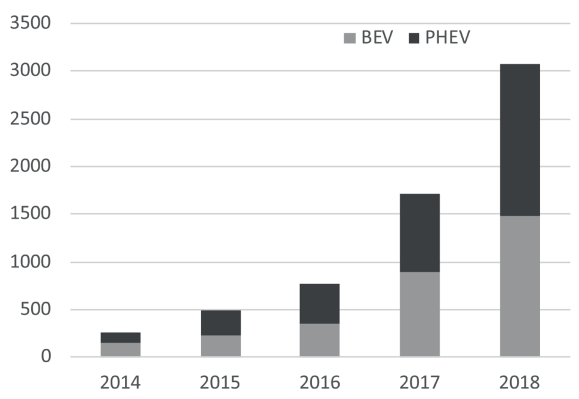

Figure 2. Number of BEV and PHEV vehicles in Poland Source: (own elaboration based on EAFO data)

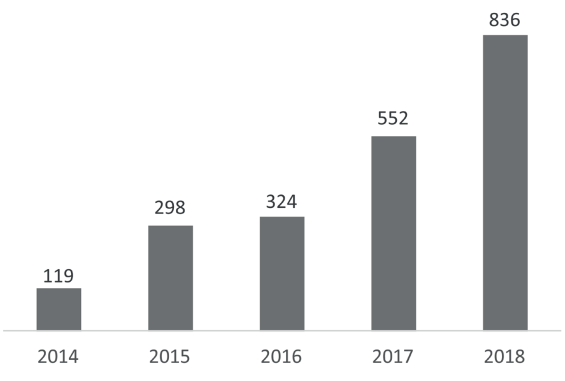

Figure 3. Number of charging stations in Poland

Source: (own elaboration based on EAFO data)

Mobility sharing services in Poland has only been developing for the last four years. The first car-sharing system was GoGet which was launched in Wrocław in July 2015. In Warsaw, 4Mobility launched its service in November 2016, followed by Panek in 2017. The largest provider is Traficar, which started services in October 2016 in Kraków, and since early 2019 has expanded to Warsaw, Wrocław, Poznań, the Tricity, and Silesia. At the end of April 2019, car-sharing systems operating in nine cities offered access to over 3,900 cars in seven biggest urban areas in Poland, with almost half of these vehicles based in Warsaw, where the services were provided by four operators (Traficar, PANEK, 4Mobility and Innogy Go). Three of them had electric vehicles in their fleet. In May 2017, the first electric car (BMW i3) appeared in GoGet's fleet. In November 2017, Vozilla started operating in Wrocław. In April 2019 this operator offered 156 - Nissan Leaf (156 vehicles), Renault ZOE (40) and Nissan e-NV200 (10). Vozilla had its own network of 10 fast-charging stations, which was to reach 22 stations in 2019.

In April 2019, PANEK fleet had over 1,100 cars available, including 1,000 hybrid (Toyota Yaris) and 10 electric (smart EQ introduced in December 2018). In turn, 4Mobility was taken over by PGE Nowa Energia. Until now, the energy company has only tested the electric car-sharing service in Siedlce (five Renault ZOEs). The company plans to increase the 4 Mobility fleet in Warsaw several times and to enter new cities. However, electric cars will only be introduced where the company will develop its own charging infrastructure.

Since December 2018, residents of Katowice can use a minute-based electric car rental service offered by TAURON eCar, with a fleet of 20 vehicles: VW e-Golf, Nissan Leaf, BMW i3 and Renault ZOE. The first 23 charging stations were launched by MAGENTA GRUPA TAURON as a complimentary service, including 4 fast-charging stations (DC) and 19 accelerated-charging stations (AC). However, it was still a project in the testing phase. In addition, since 2018 Smart City Polska has been preparing the launch of Krakow's KraCar project, offering BMW i3 vehicles. According to the operator's data, the lack of the necessary number of charging stations is currently delaying the starting date of their operation. Meanwhile, after tests and preparations carried out in 2018 Innogy Go started a commercial activity 
in April 2019 in Warsaw with 500 electric BMW i3 and the possibility of charging cars at 30 own stations. In addition, users could use 40 public charging stations.

In recent years, bike-sharing has become very popular in Poland. The biggest bike-sharing provider is Nextbike Polska, which had city bike systems in 34 Polish urban areas at the end 2018 and more than 600,000 registered and active users. Most stations have been located in the Greater Warsaw area ( 400 stations in total and over 5,600 bicycles) and in Upper Silesia (121 stations in total with around 1,040 bicycles). In April 2019, it was possible to rent 110 electrically assisted bicycles available in the Warsaw Public Bike Veturilo system. However, the largest system of shared electric bicycles on-demand in Poland and on a European scale was launched at the end of March 2019 in the Tri-City. Mevo Metropolitan Bicycle is the most modern system of urban bicycles in Europe. Residents of 14 municipalities in the Tri-City urban area can avail of 4,080 bicycles (https://rowermevo.pl).

In spring 2017, two start-ups, JedenŚlad and Blinkee, started operating, offering several electric scooters. In April 2018, around 380 scooters were available in Warsaw, of which 200 were electric ones offered by the operator of JedenŚlad. A year later, the operator provided services to individual users in Warsaw, Łódź, Tri-City, Częstochowa and Szczecin, as well as in 12 cities in the B2B segment, supporting, among others Amrest, Uber Eats, Pyszne.pl. Since May 2019, the operator has been operating under the Hop.City brand. Poznań, Wrocław and Kraków are other cities in which the operator plans to launch services. Blinkee has increased its fleet from 180 to almost 1,000 electric scooters during the first year of operation, covering over 80\% of this market. In the 2019 season, services were launched in Bydgoszcz (35 e-scooters) and Kielce (50), Koszalin replaced Kołobrzeg, while the service was withdrawn from Rzeszów and Łódź. In total, there are only 60 own vehicles; the others are owned by partners or investors who purchase and keep scooters under the management of the operator's brand.

Within half a year - from October 2018 to April 2019, 5 electric kick scooter operators started operating in Warsaw. The first was the American start-up Lime. At the beginning of April 2019, about 4,000 kick e-scooters were already available in its fleet in Warsaw, Poznań, Wrocław and Poznań. The next companies that started operations were Hive, Bird and the Lithuanian CityBee start-up, which had up until then rented out vans. At the end of April 2019, Blinkee also introduced 500 kick e-scooters to its offer. As in the operation of scooters, the operator's business model is based on free-floating and its own service technicians replacing batteries and carrying out the maintenance of vehicles.

\subsection{The Czech Republic}

From 2014 to 2018, the number of BEVs on the Czech market increased fourfold to over 2,000 vehicles; the PHEV segment had an even higher dynamic (Figure 4). The national zero-emission mobility plan assumes that the number of electric cars is to increase to 250,000 by 2030 . However, this will largely depend on how quickly and to what extent regulations are introduced regarding incentives for electric vehicle buyers - both individual and business. Despite the memorandum 
on the future of the automotive industry signed in autumn 2017, no national regulations supporting the development of e-mobility have been introduced so far.

In the years 2014-2017, about 150 charging stations were opened in the Czech Republic annually, increasing their number to over 600. This trend was stopped in 2018 (Figure 5). Most stations belong to large operators operating on the electricity market, such as: $\mathrm{C}^{\vee} \mathrm{EZ}, \mathrm{E} . \mathrm{ON}$ and PRE. The Elektromobilita network, belonging to the $\mathrm{C}^{\vee} \mathrm{EZ}$ group, at the beginning of April 2019 consisted of 90 fast-charging stations and 58 standard stations (semi-fast charging), of which 70 stations in Prague. Tesla had only four supercharger stations.

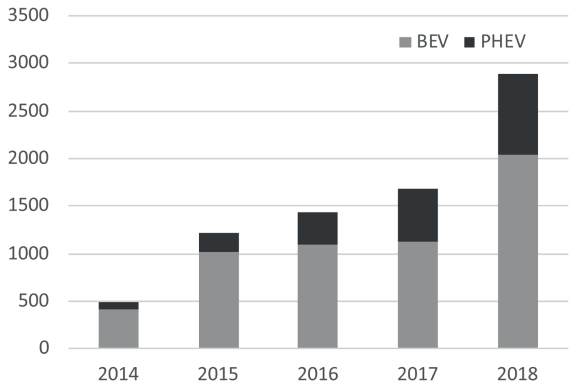

Figure 4. Number of BEV and PHEV vehicles in the Czech Republic Source: (own elaboration based on EAFO data)

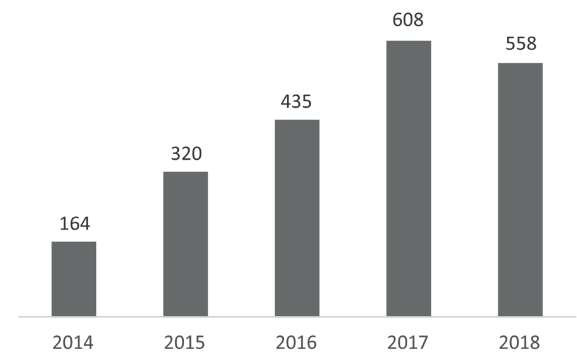

Figure 5. Number of charging stations in the Czech Republic

Source: (own elaboration based on EAFO data)

In terms of shared mobility development, Prague is the leading city, where VW e-up electric cars! and VW e-Golf can be rented and paid-for-per-minute from the car4way operator and the Re.Volt start-up, which offers rental of small 2-seater electric vehicles and motorbikes. At the beginning of 2019, 20 cars and 4 electric motorbikes were available.

In the last two years, the use of electric bicycles in tourist services in cities has also become increasingly popular. For example, e-bike tours around Prague are offered by several companies, including e-biketrip, Prague By E-bike, City Bike Prague. Prague also has a local producer of AGOGS e-bikes, which offers two-wheelers for both city and mountain riding or trekking. The bike-sharing offer has also expanded significantly. In April 2019, Prague launched its Homeport services. This system is already the fifth generation of bike-sharing, which allows you to combine a traditional and electric bike, as well as a business model using the docking and charging stations for bicycles and the so-called freebike, where bikes can be left in specific city zones and hotspots (so-called virtual stations). 500 electric bicycles were available in Prague's Homeport. The service is also being developed in another Czech city - Kladno.

At the same time, there is a growing demand for electric scooters, designed in a retro style using modern technologies. Thanks to this trend, the legendary scooter $\mathrm{C}^{2}$ ezeta was revived. It took four years to develop the prototype of the scooter currently in production. This electric scooter inspired by retro style is able to reach a speed of $123 \mathrm{~km} / \mathrm{h}$ and a range of $150 \mathrm{~km}$ on a single battery charge. In 2018, the model's production capacity was increased to 2,000 per year. In 2018, Lime, 
which offers rental of a minute-based electric kick scooters, also began operating in Prague.

\subsection{Slovakia}

Between 2017 and 2018, the number of electric cars on the Slovak market grew by almost $100 \%$ year-to-year and at the end of 2018 it reached almost 800 BEVs and 620 PHEVs (Figure 6). The first operators offering electric vehicles (up! City in Bratislava) and bicycles (Homeport in Trnava) started their activities.

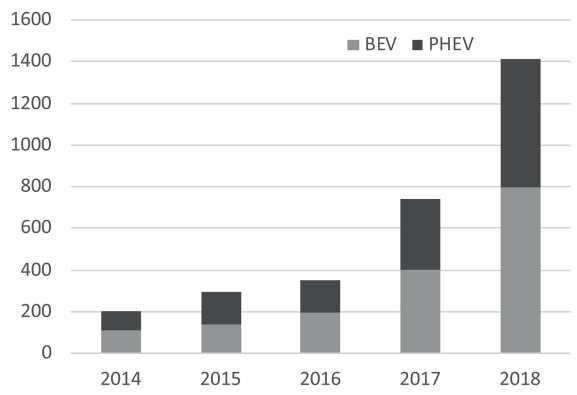

Figure 6. Number of BEV and PHEV vehicles in Slovakia Source: (own elaboration based on EAFO data)

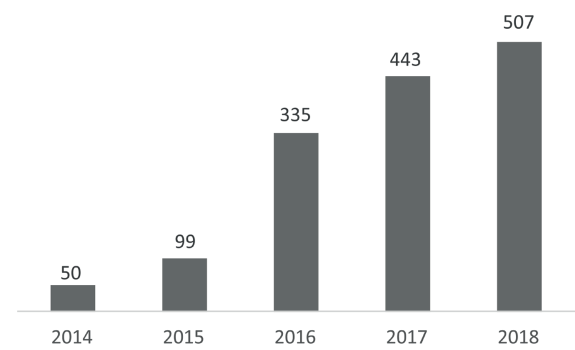

Figure 7. Number of charging stations in Slovakia Source: (own elaboration based on EAFO data)

The number of charging stations in the years 2014-2018 increased 10 times and exceeded 500 at the end of 2018 (Figure 7). Entities that develop the network of stations in Slovakia include: ZSE Energia, GreenWay, and Molgroup. Greenway's network offered the largest number of fast-charging points: 35 DC chargers, including 33 CCS connectors and 35 CHAdeMO. At the beginning of April 2019, the total number of all own stations and those managed by GreenWay in Slovakia was 93 (177 connectors).

At the end of 2018, the first ultra-fast charging station (UFC) at the Slovnaft station near Budc a (highway R1) was launched. It supports power up to 350 $\mathrm{kW}$ when connecting one car or up to $175 \mathrm{~kW}$ when two vehicles are charged simultaneously. The charger has all popular connectors (CCS Combo 2, CHAdeMO and Type 2), while the maximum power is achieved only on the cable with the CCS Combo 2 connector. Charging time of 15 minutes allows you to travel about 400 $\mathrm{km}$. The charging station was launched by ZSE Energia (part of Západoslovenská energetika, belonging to the German E.ON Group) as part of the Next-E project, which received funding from the CEF instrument with the involvement of partners from 6 countries. Ultimately, 222 fast-charging stations $(50 \mathrm{~kW})$ and 30 ultra-fast (150-350 kW) are to be built in Slovakia, Slovenia, the Czech Republic, Hungary, Croatia and Romania, including 18 fast and 7 ultra-fast in Slovakia. 


\subsection{Lithuania}

According to the EAFO's database, at the end of 2018, the number of BEVs on the Lithuanian market was 286, which together with PHEVs reached the number of about 400 vehicles (Figure 8). For BEV cars there are special license plates that allow their users to move along bus lanes and park in the city centres free of charge. The legislator did not secure other incentives that would stimulate demand for electric cars. Over 150 charging stations have been built in Lithuania over the past five years (Figure 9), including 25 along major transit roads. Vilnius has the largest number of stations available. By the end of 2019, their number is to increase from 70 to 130 . The stations will be installed by the energy company Energijos tiekimas. Elektromobiliai is another entity that develops the autoPildyk station network in various cities.

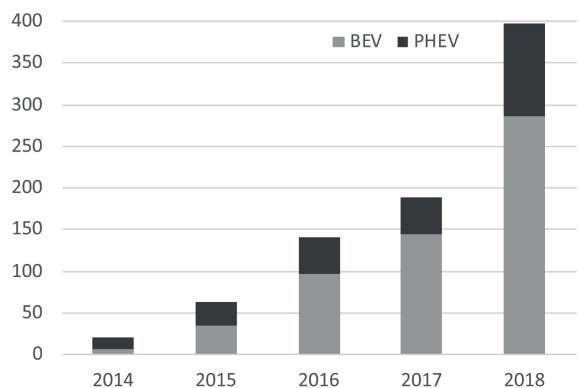

Figure 8. Number of BEV and PHEV vehicles in Lithuania Source: (own elaboration based on EAFO data)

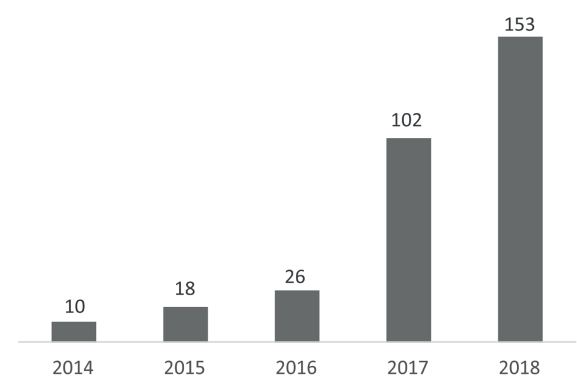

Figure 9. Number of charging stations in Lithuania Source: (own elaboration based on EAFO data)

In 2016, SPARK, a car-sharing operator, started operating in Vilnius, offering 22 VW e-up! In April 2019, 4 other BEV models could also be booked: Tesla Model X, Hyundai IONIQ, Nissan Leaf and VW e-Golf. Users could charge vehicles at 86 city points for free. In 2018, in Vilnius and Kaunas, Pasispirk launched the electric kick scooters rental service. At the beginning of 2019 five companies - CityBee, Flash, MyScooter, Swop and Unicorn Scooters - signed a memorandum with the Vilnius city municipality in order to introduce and develop the new electric scooter-sharing service. The sharing service of first 100 kick e-scooters was launched in April 2019 in Vilnius.

\subsection{Ukraine}

According to Ukravtoprom's reports, about 5,300 electric passenger cars were sold in Ukraine in 2018, i.e. twice as many as in 2017. The largest group were 3, 4 and 5-year-old vehicles (22\%, $28 \%$ and $26 \%$, respectively), while cars under 1 year - only account for $2 \%$ of all EVs. Nissan Leaf remained the most popular model (64\% of newly registered vehicles), followed by BMW i3 (7\%), Tesla Model S (5\%), Mercedes-Benz B-Class Electric Drive (3\%) and Renault Zoe (3\%). The total number of registered vehicles at the beginning of 2019 was: 10,714 BEVs and 2,264 
PHEVs. Over half of the EV registrations were in Kiev. The state-owned entities that have purchased several or more electric cars for their fleet include: Ukrenergo, Ukrposzta, National Bank, and the Verkhovna Rada of Ukraine. The MobileCar fleet consists of Nissan Leaf cars. Customers can charge cars at 12 stations.

The high dynamic of the increase in the number of personal EVs was possible thanks to the introduced exemption from VAT (16.8\%) and excise duty (EUR 109) levied on electric cars which were imported into the customs territory of Ukraine. The discounts were to apply until the end of 2018. Under the pressure of social movements, in December 2018 Act No. 9260 was adopted, under which the reduced terms for the import of electric vehicles was extended until the end of 2022. Companies providing taxi services, rental and leasing of electric cars were also covered by the VAT exemption.

In May 2018, the National Transport Development Strategy until 2030 was adopted. It assumes that electric cars in ten years will account for half of the total sales of passenger cars on the Ukrainian market. The government plans to build Tesla Gigafactory (batteries and solar panels) and launch EV production in Ukraine. The electrification of public transport in cities is also a priority. At the beginning of 2019, a working group was established at the Ministry of Infrastructure to prepare a strategy for the development of electric transport in Ukraine.

The large increase in the number of electric cars in the last two years and the projected continuation of the trend require the development of a charging station network. According to data published by the PlugShare website, at the beginning of 2019, there were a total of 1,867 charging stations in Ukraine (3697 points), of which: 1,604 publicly available (3,340 points), 159 municipal (for residents) and 104 with limited access (for companies). Almost all of them had Type 1 and Type 2 connectors for accelerated charging with alternating current and in accordance with the CHAdeMO standard. However, there was not a single fast-charging station. Most stations were located in Kiev and Odessa. Although the number of publicly available charging stations increased fivefold between 2016 and 2018 (Figure 10), the availability rate is quite low - there were 8 cars per station at the beginning of 2019. The new regulations on the design of new car parks parking lots favour the increase in the number of stations - since July $2019,5 \%$ of paid parking places must be equipped with charging stations.

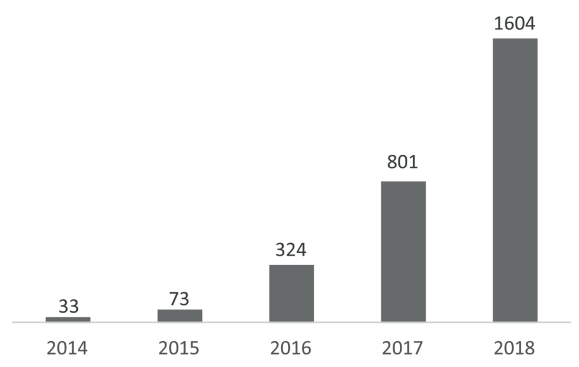

Figure 10. Number of charging stations in Ukraine Source: (own elaboration based on PlugShare data) 
The largest operators managing the station network are AutoEnterprise (about 1,900 stations) and Toka (about 140). In addition, the free electric car charging network is being developed by a Go To-U start-up together with business partners. Using of the car charging stations in various countries, including Poland, is possible with a smartphone application that supports 7 languages.

The car-sharing service of electric cars has been operating since mid-2017 in Odessa.

\subsection{Belarus}

At the beginning of 2019, about 200 electric passenger vehicles were registered in Belarus. The low number of electric vehicle owners is mainly due to two factors: the high price in relation to the local salaries, and the lack of an incentive system. In the Decree of the President of the Republic of Belarus No. 273 of July 10, 2018, which came into force on October 14, 2018, only one tax exemption was provided for EV owners. Over $90 \%$ of EVs on the Belarusian market are used cars imported from the USA or Western Europe, which requires paying a 17\% import duty rate and 20\% VAT. Although the most popular electric car among Belarusians has so far been the compact Nissan Leaf so far, there is also a small group of buyers of electric mid-range and luxury cars. According to Tesla operator, operating in Belarus since October 2016, 32 cars (S and X models) were sold in 2017-2018, although more than $50 \%$ were buyers from Russia. BMW and MINI electric cars are also available on the Belarusian market, and in November 2018 the Chinese Zotye e200 appeared on sale, which is assembled by the Belarusian-British company Unison. It was originally forecast assumed that 30,000 Zotye cars would be produced by the end of 2022 and will also be sold on other CIS markets. The price of the Zotye 200 model with a range of up to $200 \mathrm{~km}$ and a battery with a capacity of $24 \mathrm{kWh}$ is about 21,000 . USD. This is quite an exorbitant price, given the class of this city two-seater and the wealth of Belarusian society. In the absence of subsidies for the purchase of electric cars under government policy, the price of electric cars is the main barrier to the development of e-mobility in Belarus.

In October 2018, the national programme for charging infrastructure development was approved. It is assumed that in the long-term perspective until 2030, the electric car park in Belarus will increase to 25,000 vehicles. The Programme envisages the creation of 1,304 stations, including 1,224 stations in charging mode 3 and 4 in urban centres, as well as 80 stations in mode 4 on all major roads between 50-70 km apart. The programme will be implemented in three stages: 2019-2021, 2022-2025 and 2026-2030. The task of creating and developing this network was entrusted to the state-owned operator Belarusneft, which in 2018 owned a total of 560 petrol stations, including 84 electric car charging stations. The power of fast-charging stations ranges from 50 to $150 \mathrm{~kW}$. Financing of the programme is to be secured by the operator. In addition, stations can be opened by other entities. In August 2018, 26 charging stations belonged to Belarusneft. The complimentary car charging service was available until mid-2019. 
In 2017, Anytime operator began to provide its car-sharing services in Minsk. In April 2019, the services of operators Vezuha and WestGroup were also available in the Belarusian capital. However, neither had electric vehicles in their fleet.

\section{Results and Conclusions}

The summary of the results of the analysis is given in Table 1, including both general data illustrating the size of markets in these countries, as well as relative indicators: motorization rate, the share of BEV passenger cars in the total number of registered cars and the number of BEVs per one public charging station.

Table 1. Comparison of the development of electric shared mobility services in the analyzed CEE countries (as at the end of 2018)

\begin{tabular}{|c|c|c|c|c|c|c|}
\hline Indicator & Poland & $\begin{array}{l}\text { The Czech } \\
\text { Republic }\end{array}$ & Slovakia & Lithuania & Ukraine & Belarus \\
\hline Area, thousand $\left(\mathrm{km}^{2}\right)$ & 312.7 & 78.9 & 49.0 & 65.3 & 603.7 & 207.6 \\
\hline Population (million) & 38.5 & 10.6 & 5.4 & 2.8 & 42.1 & 9.5 \\
\hline $\begin{array}{l}\text { GDP (PPP) per } \\
\text { capita (IMF) (USD) }\end{array}$ & 31,939 & 37,371 & 35,130 & 34,826 & 9,283 & 20,003 \\
\hline $\begin{array}{l}\text { Number of private } \\
\text { cars (million) }\end{array}$ & 22.5 & 5,5 & 2.2 & 1.2 & 9.4 & 3.0 \\
\hline $\begin{array}{l}\text { Motorization rate } \\
\text { (cars per } 1000 \text { inhab.) }\end{array}$ & 584 & 291 & 407 & 429 & 223 & 316 \\
\hline Number of BEV & 1,486 & 2,030 & 795 & 286 & 10,714 & 200 \\
\hline $\begin{array}{l}\text { Share of BEV in total } \\
\text { number of cars }(\%)\end{array}$ & 0.01 & 0.04 & 0.03 & 0.02 & 0.11 & 0.01 \\
\hline $\begin{array}{l}\text { Direct consumer } \\
\text { incentives }\end{array}$ & $\begin{array}{c}\text { Not } \\
\text { available }\end{array}$ & $\begin{array}{c}\text { Not } \\
\text { available }\end{array}$ & $\begin{array}{c}\text { Free } \\
\text { of charge } \\
\text { parking }\end{array}$ & $\begin{array}{c}\text { Not } \\
\text { available }\end{array}$ & $\begin{array}{l}\text { Several tax } \\
\text { exemptions }\end{array}$ & $\begin{array}{c}\text { Not } \\
\text { available }\end{array}$ \\
\hline $\begin{array}{l}\text { Number of charging } \\
\text { stations }\end{array}$ & 836 & 558 & 507 & 153 & 1,604 & 84 \\
\hline $\begin{array}{l}\text { Number of electric } \\
\text { cars per one station }\end{array}$ & 3.7 & 5.2 & 2.8 & 2.6 & 8.1 & 2.4 \\
\hline Car-sharing services, & $\begin{array}{l}\text { Several } \\
\text { providers } \\
\text { in large } \\
\text { cities }\end{array}$ & $\begin{array}{l}\text { Several } \\
\text { providers } \\
\text { in large } \\
\text { cities }\end{array}$ & $\begin{array}{l}\text { Several } \\
\text { providers } \\
\text { in large } \\
\text { cities }\end{array}$ & $\begin{array}{c}\text { Several } \\
\text { providers } \\
\text { in large } \\
\text { cities }\end{array}$ & $\begin{array}{c}\text { Several } \\
\text { providers } \\
\text { in large } \\
\text { cities }\end{array}$ & $\begin{array}{l}\text { Several } \\
\text { providers } \\
\text { in Minsk }\end{array}$ \\
\hline incl. electric cars & $\begin{array}{l}\text { Warszawa, } \\
\text { Wrocław, } \\
\text { Katowice }\end{array}$ & Praha & Bratislava & Vilnius & Odessa & None \\
\hline $\begin{array}{l}\text { Micro-mobility } \\
\text { sharing services, }\end{array}$ & $\begin{array}{c}\text { Many large } \\
\text { and medium } \\
\text { cities }\end{array}$ & $\begin{array}{l}\text { Several } \\
\text { cities }\end{array}$ & $\begin{array}{l}\text { Several } \\
\text { cities }\end{array}$ & $\begin{array}{l}\text { Several } \\
\text { cities }\end{array}$ & $\begin{array}{l}\text { Several } \\
\text { cities }\end{array}$ & None \\
\hline $\begin{array}{l}\text { electric bikes, } \\
\text { scooters and kick } \\
\text { scooters }\end{array}$ & $\begin{array}{c}\text { Several large } \\
\text { and medium } \\
\text { cities }\end{array}$ & $\begin{array}{c}\text { Praha } \\
\text { and several } \\
\text { cities }\end{array}$ & $\begin{array}{c}\text { Bratislava, } \\
\text { Trnava }\end{array}$ & $\begin{array}{l}\text { Vilnius } \\
\text { and } \\
\text { Kaunas }\end{array}$ & None & None \\
\hline
\end{tabular}

Source: (own elaboration) 
The most important results and conclusions form the analysis are the following:

- Both absolute and relative indicators indicate that e-mobility in all analyzed countries is in the initial phase of its development.

- Poland is ahead of other CEE countries in terms of the development of e-mobility on-demand services both in car-sharing and micro-sharing segments. The system of shared, electrically assisted bicycles launched in March 2019 in the Tri-City is unique on a European scale.

- E-mobility on-demand services are not yet available in Belarus, and the first operators started their operations in Ukraine and Lithuania. Electric kick scooters are becoming increasingly popular among the residents of cities in Poland, the Czech Republic, Slovakia and Lithuania.

- E-mobility on-demand services are first introduced in the largest cities (usually in the country's capitals), and then in other large and medium-sized cities.

- The development of electric car-sharing services depends on the available charging infrastructure and so far it is only available in selected cities in the region.

- E-mobility on-demand services have a high development potential in the analyzed countries. At the same time, it will be a great challenge to achieve the economic effectiveness of operators offering these services.

\section{References}

Cansino, J. M., Sánchez-Braza, A., Sanz-Díaz, T. (2018), Policy Instruments to Promote Electro-Mobility in the EU28: A Comprehensive Review, Sustainability, 10(7), 2507, pp. 1-27. https://doi:10.3390/su10072507.

European Alternative Fuels Observatory, website https://www.eafo.eu.

Flügge, B. (Ed.) (2017), Smart Mobility - Connecting Everyone. Trends, Concepts and Best Practices, Springer.

Matyas, M., Kamargianni, M. (2017), A Holistic Overview of the Mobility as a Service Ecosystem, Transportation Research Conference, Gyor, pp. 1-12.

Mevo Metropolitan Bicycle, website https://rowermevo.pl.

OECD/ITF (2016), Shared mobility. Innovation for Liveable Cities, Corporate Partnership Board Report. Available from https://www.itf-oecd.org/sites/default/files/docs/ shared-mobility-liveable-cities.pdf [Accessed 5 May 2019].

Pieriegud, J. (2017), E-mobilność jako koncepcja rozwoju sektorów infrastrukturalnych. In: Paprocki, W., Gajewski, J., Pieriegud, J. (Eds.), E-mobilność: wizje i scenariusze rozwoju, Centrum Myśli Strategicznych, Sopot 2017. Available from https://www.efcongress.com/ sites/default/files/e-mobilnosc.pdf [Accessed 5 May 2019].

Spöttle, M., Jörling, K., Schimmel, M. et al. (2018), Research for TRAN Committee - Charging infrastructure for electric road vehicles, European Parliament, Policy Department for Structural and Cohesion Policies, Brussels.

Zawieska, J. (2019), Rozwój rynku elektromobilności w Polsce. In: Paprocki, W., Gajewski, J., Pieriegud, J. (Eds.), Elektromobilność w Polsce na tle tendencji europejskich o globalnych, CeDeWu, Centrum Myśli Strategicznych, Sopot 2019. Available from https://www. efcongress.com/sites/default/files/elektromob_internet.pdf [Accessed 3 June 2019].

\section{Corresponding author}

Jana Pieriegud can be contacted at: jana.pieriegud@sgh.waw.pl 